\title{
Otizm Spektrum Bozukluğu Olan Çocuklarda Sembolik Oyun
}

\author{
Deniz Tahiroğlu
}

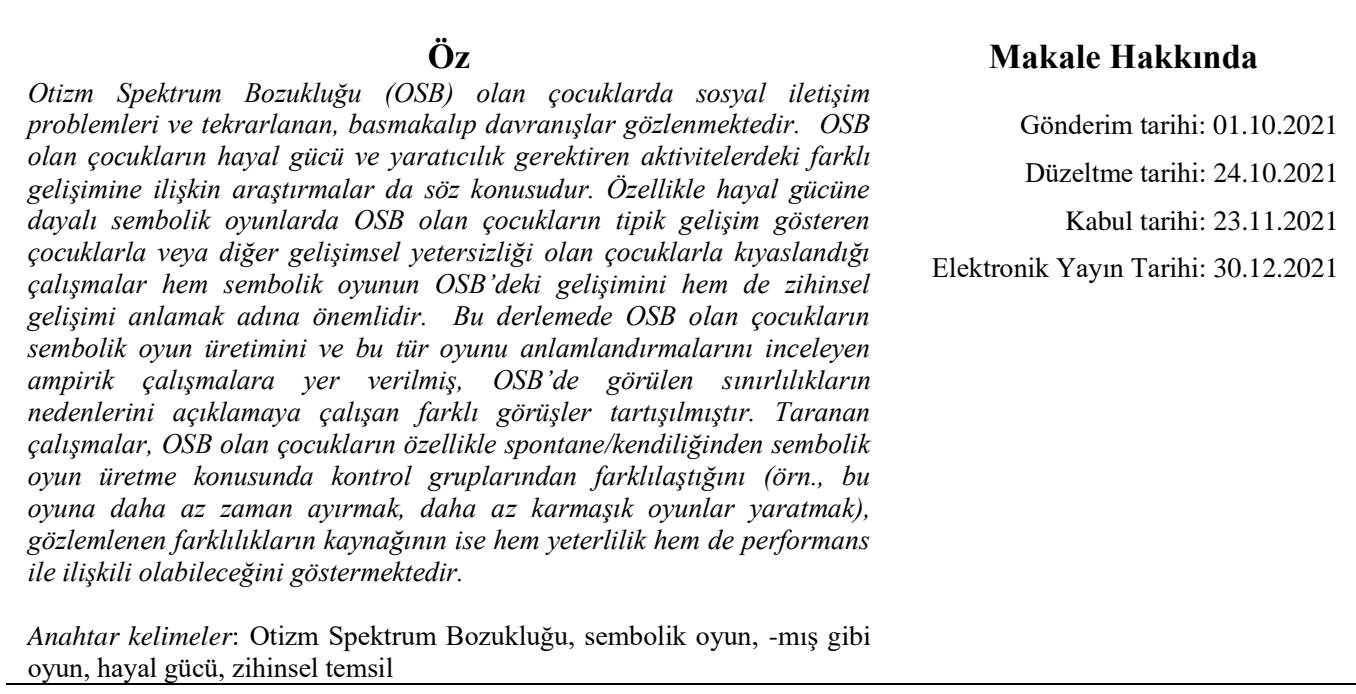

\section{Otizm Spektrum Bozukluğu Olan Çocuklarda Sembolik Oyun}

Otizm Spektrum Bozukluğu (OSB), etkileri erken yaștan itibaren gözlemlenen karmaşık bir nörogelişimsel bozukluktur (American Psychiatric Association [APA], 2013). OSB tanısında öne çıkan iki temel belirti, sosyal iletişimdeki yetersizlikler ve tekrarlanan/kısıtlı davranışlar ya da ilgi alanları olarak belirtilmektedir (APA, 2013). Bu sınırlılıklarla birlikte, OSB olan çocukların hayal gücü ve yaratıcılık gerektiren aktivitelerdeki farklı gelişimi de araştırmacılar ve alanda çalışan uzmanlar tarafından tartış1lmaktadır (González-Sala vd., 2021; Kasirer vd., 2020; Scott, 2013). Bu kapsamda sıklıkla ele alınan konulardan biri de hayal gücüne dayanan sembolik oyunun ${ }^{\mathrm{a}}$ OSB olan çocuklardaki gelişimsel seyridir.

Tipik gelişim gösteren çocuklarla yapılan çalışmalar sembolik oyunun 18-24 ay arasında gözlenmeye başladığını, okul öncesi dönemde hızla artış gösterdiğini ve bu

Boğaziçi Üniversitesi, Psikoloji Bölümü, deniz.tahiroglu@boun.edu.tr, ORCID: 0000-0003-3871-8811

a 'Sembolik oyun' (symbolic play) ve '-mış gibi oyun' (pretend play) bu derlemede benzer anlamlarda kullanilmaktadır. 
oyun türünün çocukların sosyal (örn., sosyal beceriler) ve bilişsel (örn., dil) gelişimleriyle yakından ilişkili olduğunu göstermektedir (Lillard vd., 2013). OSB olan çocuklarla yapılan çalışmalarda ise sembolik oyunun bu grupta daha geç geliştiği ya da gelişiminde sinırlılıklar olduğu gösterilmektedir (González-Sala vd., 2021; Jarrold ve Conn, 2011). Bu derlemede, OSB olan çocuklardaki sembolik oyunun gelişimi, bu grubun farklı kontrol gruplarıyla (örn., tipik gelişim ya da farklı gelişimsel bozukluklar gösteren akranlarıyla) sembolik oyunu anlama/kavrayış (örn., Bigham, 2008) ve oyun üretimi açısından (örn., Lam ve Yeung, 2012; Rutherford vd., 2007) kıyaslandıkları çalışmalara yer verilerek incelenecektir. Derlemenin amacı, tipik gelişim gösteren çocuklarda sosyal ve bilişsel gelişime destek olduğu düşünülen hayal gücüne dayalı oyunların (Lillard vd., 2013) OSB'deki gelişimsel seyrini incelemek ve bu sayede OSB'li çocukların zihinsel gelişimlerine dair daha fazla bilgi sahibi olmaktır. Sembolik oyunun OSB'de incelenmesi bu oyun türünün gelişimi hakkındaki kuramlar için de önemlidir. Ayrıca, derlenen bu bilgilerin OSB olan çocukları hedef alan uygulamalara da (örn., özel eğitim programları) katkı sunması beklenmektedir.

Birçok araştırma OSB olan çocukların tipik gelişim gösteren akranlarına ve farklı gelişim geriliği gösteren gruplara kıyasla hayal gücüne dayalı olan sembolik oyunda problem yaşadığını göstermiştir (Charman vd., 1997; Hobson vd., 2013; Jarrold vd., 1996; Rutherford vd., 2007). Yakın zamanda yapılan çalışmalarda da OSB olan çocuklarda gözlemlenen belirtilerin şiddetiyle çocukların sembolik oyun davranışları arasında bir ilişki olduğu (Campbell vd., 2016) ve bebeklik döneminde sembolik oyunda gözlemlenen gerilik ve/veya eksikliğin ileriki yaşlardaki OSB tanısında güçlü bir yordayıcı faktör olduğu gösterilmiştir (Barbaro ve Dissanayake, 2013).

Alanyazında OSB olan çocuklarla tipik gelişim gösteren çocuklar arasındaki sembolik oyun davranışlarındaki farklılıkları gösteren çalışmalar büyük ölçüde kabul görmesine rağmen (González-Sala vd., 2021; Jarrold, 2003) gruplar arası farklılık bulamayan çalışmalar da (Dominguez vd., 2006; Naber vd., 2008; Thiemann- Bourque vd., 2012) mevcuttur. Çalışmaların sonuçlarındaki farklılıkların nedenlerinden biri katılımcıların özellikleri (örn., OSB’li çocukların spektrumda farklı düzeylerde olması; kontrol gruplarının kimlerden ve nasıl oluşturulduğu) olabilirken bir diğer önemli neden ise çalışmalarda kullanılan testler ve yöntemsel farklılıklar olabilir. Bazı çalışmalarda çocukların oyun üretimleri yapılandırılmamış/serbest oyun görevleri kullanılarak gözlemlenirken (örn., Rutherford vd., 2007) bazı çalışmalarda yapılandırılmış oyun yöntemleri kullanılmış (örn., Charman ve Baron-Cohen, 1997) ve bazı çalışmalarda ise oyun üretiminden ziyade sembolik oyunun anlaşılmasına (örn., Bigham, 2008) odaklanılmıştır.

Kullanılan ölçüm yöntemlerinin de etkisiyle OSB olan çocuklarda sembolik oyun gelişimine etki eden faktörler farklı araştırmacılar tarafından farklı şekillerde açıklanmıştır (Jarrold ve Conn, 2011; Rutherford ve Rogers, 2003). Bazı çalışmalarda OSB olan ve olmayan gruplar arası farklılıkların kaynağı olarak yeterlilikle ilgili problemler gösterilirken (sembolik oyun için gerekli olan bilişsel donanıma sahip olmamak, örneğin zihinsel temsil yaratmayla ilgili problemler; Baron-Cohen, 1987) bazı araştırmacılar gözlemlenen farkları performans eksikliği ile (örneğin çocuğun bu tür oyunu oynamak için motive olmaması ya da oyun için fikir üretiminde karşılaşılan zorluklar; Hobson vd., 2009; Jarrold vd., 1996) açıklamaktadır. Bu derlemede, OSB olan çocukların sembolik oyun üretimi ve anlayışını farklı testler kullanarak 
değerlendiren çalışmaların sonuçları aktarılarak bu oyun türünün OSB'deki gelişimi incelenecektir. Çalışmaların sonuçlarının OSB olan çocukların hayal gücü gerektiren aktivitelerdeki performanslarını açıklayan farklı görüşlerle ilişkilendirilerek tartışılması hem tipik gelişim gösteren hem de OSB olan çocukların zihinsel gelişimini anlamaya yardımcı olacaktır.

\section{Otizm Spektrum Bozukluğunda Sembolik Oyun Üretimi}

OSB olan çocuklarda yapılan çalışmaların çoğu sembolik oyun üretimindeki sınırlılıklara işaret etmektedir. OSB'li çocukların sembolik oyun konusunda tipik gelişen kontrol gruplarından farklı olmadığını bulan çalışmalar olsa da (Dominguez vd., 2006; Lewis ve Boucher, 1988), birçok çalışma bu alandaki farklılıklara dikkat çekmektedir (Jarrold ve Conn, 2011; Lam ve Yeung, 2012). Yapılan çalışmalarda hem çocukların spontane, kendi kendilerine içten gelen bir şekilde yarattığı sembolik oyun (örn., Lam ve Yeung, 2012), hem de yönlendirildiklerinde ya da komut verildiklerinde üretebildikleri sembolik oyun (örn., Rutherford vd., 2007) araştırılmıştır.

Sadece birkaç çalışma OSB olan grupların kendiliğinden gelişen sembolik oyun üretiminde kontrol gruplarıyla benzer performans gösterdiğini bulmuştur. Örneğin, Lewis ve Boucher (1988) çocukların farklı oyuncak setleriyle oyunlarını gözlemlemiş ve kontrol gruplarıyla (tipik gelişen ve orta derecede öğrenme güçlüğü olan çocuklar) OSB olan gruplar arasında sembolik oyunda geçirilen zaman açısından bir fark bulunmadığını göstermiştir. Benzer şekilde, Dominguez vd. (2006) ve Morgan vd.'nin (2003) çalışmalarında da OSB olan çocukların sembolik oyun davranışlarında geçirdikleri süre tipik gelişim gösteren akranlarından farklılaşmamıştır. Bunlara ek olarak, Christensen vd. (2010) ise halihazırda OSB tanısı olan çocukların kardeşleri (OSB için yüksek risk grubu) ile yaptıkları çalışmada, daha sonradan OSB tanısı almış, sonradan başka gelişimsel gerilik tanısı almış ve tipik gelişim gösteren 18 aylık bebeklerin oyun davranışlarını incelemişlerdir. Bebeklerin kendilerine verilen oyuncaklarla oynama süre ve şekilleri kodlandığında daha sonradan OSB teşhisi konmuş bebeklerin sembolik oyun davranışlarında (örn., tabağı şapkaymış gibi yaparak kafaya koymak) tipik gelişim gösteren kontrol grubundan ayrılmadıkları bulunmuştur. Ancak, Christensen vd.(2010) bu sonuçları yorumlarken dikkatli olunması gerektiğini çünkü 18 aylık bebeklerin sembolik oyun davranışı için çok küçük olmalarından kaynaklı gözlemlenen taban etkisinden ötürü grupların ayrışmamış olabileceğini öne sürmüştür (bk. Wilson vd., 2017).

OSB olan çocukların tipik gelişim gösteren çocuklarla kendiliğinden gelişen sembolik oyunda benzer olduğunu gösteren yukarıda tartışılan az sayıda çalışmaya kıyasla, OSB olan çocukların kendiliğinden gelişen sembolik oyunda problem yaşadığını gösteren çalışmaların sayısı çok daha fazladır (Jarrold ve Conn, 2011). Bu çalışmalarda, farklı yaş grupları (tanı almış okul öncesi ve okul çağı çocukları ya da risk grubundaki daha küçük yaştaki çocuklar), farklı kontrol grupları (tipik gelişim gösteren ya da farklı gelişim geriliği tanısı olan), farklı oyun partnerleri (tek başına ya da ebeveyn veya araştırmacıyla birlikte), farklı süreler (5 dakika veya daha uzun), farklı oyuncaklar ve farklı test ortamları (ev ya da klinik/terapi odası) kullanılmıştır. Çalışmalardaki ortak bulgu ise OSB olan çocukların tipik gelişen gruplara ve farklı gelişimsel bozuklukları olan çocuklara kıyasla daha az sembolik oyun oynamaları (Lam 
ve Yeung, 2012; Rutherford ve Rogers, 2003), bu oyunlarda da daha çok basmakalıp ve tekrarlayan davranışlar göstermeleri (Hobson vd., 2013; Wing vd., 1977) ve daha az karmaşık oyunlar yaratmalarıdır (Wilson vd., 2017).

OSB olan çocukların yapılandırılmamış/serbest oyun ortamındaki sembolik oyun davranışını orta derece öğrenme güçlüğü yaşayan çocuklarla kıyaslayarak inceleyen bir çalışmada Jarrold vd. (1996), yukarıda anlatılan Lewis ve Boucher'in (1988) çalışmasından farklı sonuçlar elde etmiştir. Sonuçlar arası farklılık yorumlanırken, Jarrold vd. Lewis ve Boucher'in (1988) çalışmasında OSB olan çocukların yapılandırılmamış sembolik oyunda kontrol grubundan farklılık göstermemelerinin sebebinin yöntemsel olabileceğini iddia etmiştir. Jarrold vd. (1996), önceki çalışmalarda kullanılan oyuncakların (örn., oyuncak araba) sembolik oyun için çok elverişli olmadığından hem OSB olan grupta hem de kontrol gruplarında çok az sembolik oyun gözlendiğini (taban etkisi) ve bunun gruplar arası farklılıkları maskelemiş olabileceğini öne sürmüştür. Önceki çalışmalardan farklı materyaller (oyuncak bebekler ve kendi başına çok işlevi olmayan ıvır zıvır materyaller, örn., küçük bir sünger parçası) kullanılarak yürütülen çalışmada, OSB olan çocukların kontrol grubuna göre daha az sembolik oyun davranışı gösterdikleri ortaya konmuştur. Benzer sonuçlar, OSB olan çocukların tipik gelişim gösteren (Charman vd., 1997; Lam ve Yeung, 2012; Mundy vd., 1986; Rutherford vd., 2007) ya da farklı gelişimsel geriliği olan çocuklarla (Baron-Cohen, 1987; Charman vd., 1997; Libby vd., 1997) kıyaslandıkları çalışmalarda da bulunmuştur.

Wilson vd.'nin (2017) çalışmasında ise daha sonradan OSB tanısı alan çocukların 9-12 ve 15-18 aylıkken evlerinde çekilen videoları kodlanarak çocukların oyun davranışları tanı almamış, tipik gelişim gösteren çocuklarınkiyle kıyaslanmıştır. Christensen vd.'nin (2010) çalışmasından farklı olarak, Wilson vd. (2017) daha sonradan OSB tanısı alan grubun oyunlarının daha az karmaşık olduğunu, bu grupta daha az sembolik oyun gözlemlendiğini ve zaman içinde, yaşla birlikte fazla bir gelişme gözlenmediğini raporlamıştır.

Kendiliğinden gelişen sembolik oyuna örnek olabilecek başka bir aktivite ise hayali arkadaşa sahip olmaktır. Hayali arkadaşlar çocukların yarattığı, kişilik atfettiğ i ve iletişime girdiği görünmez varlıklar (invisible friends) ya da kişileştirilmiş nesnelerdir (personified objects; Taylor, 1999). Yapılan çalışmalar, tipik gelişim gösteren çocukların yaklaşık \%30-50'sinin hayatının bir döneminde hayali arkadaşa sahip olduğunu ortaya koymaktadır (Gleason ve Hohmann, 2006; Motoshima vd., 2014). Tipik gelişim gösteren ve OSB olan grupların kıyaslandığı bir çalışmada OSB grubunda hayali arkadaşa sahip olma oranının çok daha düşük olduğu (16\%; Davis vd., 2018) ve hayali arkadaşların özelliklerinde de farklılaşmalar olduğu gözlenmiştir. Örneğin tipik gelişim gösteren çocukların hayali arkadaşları daha çok görünmez özellikteyken OSB grubunda raporlanan hayali arkadaşların daha çok kişileştirilmiş nesneler olduğu bulunmuştur (Davis vd., 2018).

Çocukların kendiliğinden gelişen oyunlarında gösterdikleri farklılıkları açıklamaya çalışan araştırmacılar sembolik oyunda gerçekliğin göz ardı edilmesi ve yeni fikir ve davranışlar üretiminin gerekliliğine dikkat çekerek OSB olan çocuklarda gözlemlenen zorlukların bir kısmının bu üretim sürecinden kaynaklanabileceğini öne sürmüşlerdir (Jarrold vd., 1993; Lewis ve Boucher, 1995). Bu nedenle de eğer ortam daha elverişli hale getirilip araştırmacı çocuğu fikirler üretmesi yönünde teşvik ederse 
çocukların sembolik oyun üretebilecekleri öne sürülmüş ve bu hipotezi test etmek için çocukların yönlendirmeler sonucu ürettikleri oyunlar incelenmiştir (Charman ve BaronCohen, 1997; Jarrold vd., 1996).

Çalışmalarda ağırlıklı olarak OSB tanısı alan çocukların serbest oyunda ve daha fazla yapılandırılmış ortamlarda/bağlamlardaki sembolik oyunu karşılaștırılmıştır (Jarrold, 2003). Örneğin, yukarıda da sözü geçen çalışmada, Jarrold vd. (1996) OSB olan ve orta düzey öğrenme güçlüğü gösteren çocukların kendiliğinden yarattığı serbest oyunu ve oyun içinde hatırlatma/yönlendirme yapılan (elicited) oyunlarını karşılaştırmıştır. Çocuklardan kendilerine verilen oyuncaklarla neler yapabileceklerini göstermeleri istenmiştir. Daha önce de tartışıldığ olan grup, kontrol grubuna göre çok daha az sembolik oyun üretmiştir. Ancak, çalışmanın hipoteziyle uyumlu olarak yapılan hatırlatmalar/yönlendirmelerin genel sembolik oyun düzeyini yükselttiği bulunmuştur.

Charman ve Baron-Cohen (1997) de önceki çalışmalarla tutarlı olarak (Jarrold vd., 1996) hem OSB olan grupta hem de zihinsel engeli bulunan çocuklarda hatırlatma/ yönlendirmeler sonucu sembolik oyunda artış bulmuştur. Çalışmada çocuklara iki işlevsel oyun görevi ve bunlara uygun materyal (örn., bir bebek ve oyuncak kaşık) ve iki obje ikame görevi ve bunlara uygun materyal (bir objenin diğeri yerine kullanılmasını gerektiren görev, örn., bir bebek ve metal bir çubuk) sunulmuştur. Araştırmacı ilk olarak çocuklara bu objelerle neler yapabileceğini sormuştur. Bu sorunun ardından eğer çocuk cevap vermezse çocuğa objeyle - mış gibi oynaması için spesifik bir ipucu/talimat verilmiştir (örn., hadi şimdi -mış gibi yapalım - bebeğe meyve suyu ver). Bu ipucu/talimatın da çalışmadığı, çocuğun davranışını tetiklemediği durumlarda araștırmacı davranıșı modellemiștir. Charman ve Baron-Cohen (1997) eğer çok fazla ipucu sunulursa OSB olan çocukların basit sembolik oyun (örn., bir objeyi başka bir obje yerine kullanma) üretebildiklerini göstermiştir.

Thiemann-Bourque vd. (2012) ise sembolik oyun davranışında OSB olan çocuklar ile gelişim geriliği olan çocuklar arasında benzerlik bulmuşlardır. OSB olan ve gelişim geriliği olan çocuklarla yürütülen bu çalışmada, biri yapılandırılmamış (oyuncakların sunulup herhangi bir talimat verilmemesi) ve dördü yapılandırılmış (deneyi yürüten kişinin çocuklara yapmalarını istediği sembolik oyunu kısaca anlatması) olmak üzere beş oyun setinde çocukların oyun davranışları incelenmiştir. Çalışma sonucunda sembolik oyun çocuklar tarafından en az tercih edilen oyun olmakla beraber OSB olan ve gelişim geriliği olan gruplar sembolik oyun davranışında birbirlerinden anlamlı biçimde ayrışmamıştır (Thiemann-Bourque vd., 2012).

Burada gözden geçirilen çalışmalar, OSB olan çocukların yapılandırılmamış, kendiliğinden gelişen sembolik ( - mış gibi) oyunda bazı sınırlılıklar göstermesine rağmen yapılandırılmış koşullarda sembolik oyuna benzer davranışlar gösterebildiklerini ortaya koymaktadır. Bu yapılandırılmış koşullardaki oyun da çoğu zaman kontrol gruplarına kıyasla daha basit ve farklı bulunmasına rağmen (Jarrold vd., 1996. Rutherford vd., 2007), yine de OSB olan çocukların bu koşullarda -mış gibi oyun üretmeleri, onların bu konuda beceri ve kapasitelerinin olduğunu ancak bunu spontane bir biçimde gösteremediklerine işaret edebilir. Bunun nedenleri arasında da zihinsel/kavramsal yetersizlikten ziyade çocukların motivasyon eksikliği ya da üretimden kaynaklı problemler olduğu düşünülebilir. Ancak, farklı görüşteki araştırmacılara göre bu çalışmalardaki yapılandırılmış ve hatırlatma/yönlendirme 
yapılmış koşullardaki çocuklar, verilen görev için en uygun olan objeyi seçmek ve buna uygun sembolik oyun davranışında bulunmaktadır. Burada çocukların yaptıkları davranışın temsil becerisi gerektirmediği, çocukların sadece akıllıca bir akıl yürütmeyle de bu testleri başarabileceği de öne sürülmektedir (Charman ve Baron-Cohen, 1997).

\section{Otizm Spektrum Bozukluğunda Sembolik Oyunu Anlama}

Oyun üretimine dayalı testlerin kullanıldığı çalışmaların sonuçları (örn., OSB olan çocukların kontrol gruplarına kıyasla daha az ve daha basit sembolik oyun üretmesi), OSB olan çocuklarda gözlemlenen farklılıkların kaynağının zihinsel olarak farklı gelişim mi (örn., zihinsel temsil becerisindeki problemler) yoksa tamamen performansla alakalı problemler mi olduğunu ayrıştırma konusunda yeterli değildir (Jarrold vd., 1994b). Bu nedenle, çeşitli araştırmalarda çocukların yeterliliklerini, zihinsel temsil becerilerini, ölçmek amacıyla çocukların bu tür oyunu anlayıp anlamadıkları araştırılmıştır. $\mathrm{Bu}$ sayede, oyun üretimine dayalı testlerin kullanıldığı çalışmalarda performans problemlerinin gölgeleyebileceği yeterlilik problemlerinin daha açıkça test edilebileceği savunulmuştur (Jarrold vd., 1994b).

OSB olan çocukların sembolik oyunu anlama/kavrayış becerilerini inceleyen araştırmaların büyük bir kısmı çocukların sembolik oyun anlayışlarında sorun yaşamadıklarını göstermektedir (örn., Jarrold vd., 1994b; Kavanaugh ve Harris, 1994). $\mathrm{Bu}$ çalışmalarda araştırmacı, çocuklara bir dizi -mış gibi davranış gösterir ve çocuklardan bu -mış gibi davranışın sonucunu belirtmesini ister. Örneğin, araştırmacı oyuncak bir ördeğin üzerine çay dökermiş gibi yapar ve sonrasında çocuğa 'Ördek şimdi nasıl görünüyor?' diye sorar (Kavanaugh ve Harris, 1994). Çocuklar kendilerine gösterilen üç resimden (-mış gibi yapılan değişime uygun resim--çayla ıslanmış bir ördek, alakasız bir değişikliği gösteren bir resim -- üzerinde kırmızı üçgenler olan bir ördek ve oyuncağın şimdiki halini gösteren bir resim -- kuru bir ördek) birini seçerler. OSB olan çocukların araştırmacının bu tür -mış gibi davranışlarını anlama performansları rastlantısal şans seviyesinin üzerinde bulunmuştur: Çocuklar araştırmacının -mış gibi yaptığı değişime uygun resmi bulmakta zorlanmamışlardır (Jarrold vd., 1994b; Kavanaugh ve Harris, 1994).

Bu çalışmalara dayanarak araştırmacılar OSB olan çocukların sembolik oyunu anlayabildiklerini (zihinsel temsil yaratabildiklerini) ve bu alanda problem yaşamadıklarını savunurken; Bigham (2008) bu çalışmaların OSB olan çocukların sembolik oyunu anladıklarını savunmak için yetersiz kaldığını belirtmiştir. Bigham (2008), Kavanaugh ve Harris (1994) ve Jarrold vd.'nin (1994b) yaptıkları çalışmalarda farklı formları olan sembolik oyunun (Leslie, 1987) sadece bir formuna odaklanıldığını belirtmiştir. Bigham'a (2008) göre yukarıda sözü edilen çalışmalarda çocukların bir objeye ‘olmayan' özellikler yükleme davranışını (ördek gerçekte temizken kirliymiş gibi davranma) anladıkları gösterilmiştir. Ancak sembolik oyunun farklı formları olan çocukların bir objeyi bir başka objenin yerine koyma davranışını (muzu telefonmuş gibi kullanmak) ya da hayali bir obje ile etkileşime geçme davranışını (hayali bir bardaktan su içermiş gibi yapmak) ölçmeyen bu çalışmalar OSB'li çocukların sembolik oyunu anlamalarında ve zihinsel temsil yaratmada sorun yaşamadıklarını iddia etmek için yeterli değildir. 
Bigham (2008, 2010), yaptığı çalışmalarda çocukların bir objeyi başkasının yerine kullanma ve hayali bir obje ile etkileşime geçme davranışlarını anlayıp anlamadıklarına bakmıştır. Çalışmaya OSB olan ve orta düzey öğrenme güçlüğü gösteren çocuklar katılmış ve performansları önceki bir çalışmada yer alan tipik gelişim gösteren çocuklarla kıyaslanmıştır. Çocuklardan araştırmacının sergilediği bir objenin başka bir obje yerine konması davranışlarını anlaması beklenmiştir. Bu davranış farklı seviyelerde incelenmiştir; her eylemde kullanılan objelerin şekilleri ve işlevleri bozularak çocukların sembolik davranışları anlayabilme yetileri ölçülmüştür; çünkü benzer şekil ve işleve sahip eşyaları 'o objeymiş gibi kullanma' davranışının, başka şekil ve işleve sahip eşyalarla -mış gibi yapmaktan daha kolay olduğu düşünülmektedir. Örneğin, çay dökme eylemi için "benzer şekil ve işlev" aşamasında oyuncak çay bardağı, "benzer şekil, benzer olmayan işlevde" biberlik, "belirsiz şekil ve işlevde" ise bir kap kullanılmıştır ve çay bardağının kullanıldığı koşulda çocuğun -mış gibi yapılan eylemi biberliğin kullanıldığı koşula kıyasla daha kolay anlaması beklenmektedir. Deneyi yürüten kişi katılımcılara ilk önce "Ne yapıyorum?”; cevap alamazsa "Neyi -mış gibi yapıyorum?"; ve hala cevap alamazsa, “-mış gibi yaptığım obje nedir?” sorularını yöneltmiştir. Beklendiği üzere, OSB olan çocuklar gerçek ve gerçek boyuttaki oyuncakların kullanıldığı aşamalarda kontrol grubu çocuklarından ayrışmamışlardır. Ancak, araştırmanın hipotezleriyle uyumlu olarak OSB olan çocuklar daha farklı seviyelerdeki -mış gibi davranışları anlamada (örn., belirsiz şekil ve işlevdeki bir objeyle -mış gibi yapılan davranış) kontrol gruplarına göre daha başarısız olmuşlardır.

Özetle, sembolik oyunu kavramaya yönelik çalışmalara göre, OSB olan çocukların bir objeye 'olmayan' özellikler yükleme davranışını anlayabildikleri (Jarrold vd., 1994b; Kavanaugh ve Harris, 1994); ancak, objeyi başka bir obje yerine koyma ve hayali objeler uydurma gibi sembolik oyunları anlamakta güçlük çektikleri gözlenmiştir (Bigham, 2008; 2010). Bulgular arası farkları yorumlarken Bigham (2010), önceki çalışmalarda kullanılan materyaller nedeniyle (hayali çay, çay ile ilişkili olan çay bardağından dökülüyor) OSB olan çocukların zorlanmadığını çünkü bu tür koşullarda işlev ve şekil benzerliği olduğu için zihin temsili yaratılmasına gerek olmadığını öne sürmüştür. Ancak sembolik oyun anlayışının bozulmamış olduğunu iddia etmek için şekil ve işlev değişikliğinin de anlaşılması gerektiğini savunarak OSB'de bunun eksik olduğunu göstermiş ve bu çocuklarda gözlemlenen sembolik oyun davranışlarındaki farkın 'yeterlilik' (zihinsel temsil becerisi) ile ilgili olduğu sonucuna varmıştır (Bigham 2008; 2010).

\section{Otizm Spektrum Bozukluğunda Gözlemlenen Farkların Açıklanması}

OSB olan çocukların sembolik oyunlarında gözlemlenen gelişimsel farklılığın, yetersizlikten mi (zihinsel temsil kuramı gelişimindeki problemler) yoksa performanstan mı (yürütücü işlevlerde gözlenen problemler ya da motivasyon eksikliği) kaynaklı olduğu konusu hem OSB'yi daha iyi anlamak hem de olası müdahale programları için temel oluşturmak adına oldukça önemlidir. Dolayısıyla, bu bölümde yukarıda kısaca özetlenen çalışmalara referans verilerek farklı perspektifler incelenecektir.

Çalışmalarda araştırmacıların kullandıkları görevler arasında büyük farklılıklar gözlenmektedir. Çalışmalarda sembolik oyunun hangi yönünün araştırıldığı (örn., oyunu anlama veya üretme) bu çalışmalardan yapılabilecek çıkarımları da etkilemektedir. 
Örneğin, yapılandırılmamış koşullarda sembolik oyun üretmeye dayalı araştırma yöntemleri OSB olan çocuklarda gözlemlenen farklıkların yeterlilik mi yoksa performans ile mi ilgili olduğunu göstermede yetersiz kalmaktadır. Çünkü, serbest oyunda sembolik oyun davranışı göstermeyen OSB olan çocuklar, yeterlilik bakımından eksik olabilecekleri gibi (örneğin, zihinsel temsil becerilerindeki problem sembolik oyunu engelliyor olabilir); gerekli yeterliliklere sahip olmalarına rağmen farklı nedenlerle sembolik oyun davranışı göstermiyor olabilirler (örneğin, oyun için fikir üretiminde yaşadıkları sorunlar; Jarrold vd., 1996). Dolayısıyla bu tür çalışmalar, performans eksikliğinin maskeleyebileceği bir yeterlilik eksikliğini ölçmeye izin vermemektedir (Jarrold vd., 1994b). Bu nedenle, bazı araştırmacılar çocukların başkalarının yaptığı sembolik oyun davranışını nasıl anladıklarını incelemenin yeterlilik mi yoksa performans eksikliği mi sorusunu araştırmak için daha uygun olduğunu savunmuştur. Kullanılan bu yöntem sayesinde çocukların sembolik oyun üretim davranışlarına bakılmaksızın çocukların kavramsal olarak sembolik oyun anlayışları çalışılabilmekte ve bu oyunu anlayan çocukların zihinsel temsil becerilerinde problem olmadığı savunulabilmektedir (Jarrold vd., 1994b; Kavanaugh ve Harris, 1994). Diğer yandan, bazı araştırmacılar ise farklı şekillerde yapılandırılmış (örn., araştırmacının yönlendirmelerde bulunduğu) oyun görevlerini kullanarak OSB'li çocuklarda gözlenen farkların yeterlilik mi yoksa performans kaynaklı mı olduğu konusuna açıklık getirmeye çalı̧̧mışlardır.

\section{Zihinsel Temsildeki Problemler}

Leslie'ye göre (1987) sembolik oyunu anlamak ve oynamak için aynı anda iki temsili zihinde tutabilme yetisi gerekmektedir: Birinci temsil objenin kendisi iken; ikinci temsil objenin kendisinin yeni bir temsilidir. Bu yeni temsil objenin kendisinden ayrıştırılmış bir kopyasıdır (decoupled copy) ve bu sayede örneğin objenin kendisi olan muz ve birinci temsildeki "bu bir muzdur" temsili, ikinci temsilde "bu muz, bir telefondur" şeklini alabilir (Leslie, 1987, s. 417). Bu zihinsel temsil, alanyazında üst-temsil (metarepresentation) olarak adlandırılmaktadır (Leslie, 1987).

Tipik gelişimde iki yaş civarında ortaya çıkan üst temsil becerisi/zihinsel temsil yeteneği daha sonradan (4 yaş civarı) ortaya çıkacak olan zihin kuramı becerisinin de (kendimizin ve başkalarının zihinsel durumlarının davranışlar üzerindeki etkisini anlama) temelini oluşturur (Leslie, 1987) ve Leslie'ye göre sembolik oyun ve zihin kuramı aynı mekanizma üzerinden çalışır. Zihin kuramının OSB olan çocuklarda, Down Sendromlu ve tipik gelişim gösteren çocuklara kıyasla gelişmediğini gösteren çalışmalar mevcuttur (Baron-Cohen vd., 1985). Bununla birlikte OSB olan çocuklarda gözlemlenen sembolik oyun farklarının da bu gruba özel olduğu düşünülmektedir. Üretilen sembolik oyunlar karşılaştırıldığında, OSB olan çocuklar kendileriyle dil ve zeka gelişimi açısından eşleşmiş olan Down Sendromlu çocuklara kıyasla daha az sembolik oyun göstermektedir (Baron-Cohen, 1987). Bu sonuçlara dayanarak, Leslie (1987) OSB olan çocukların hem basit seviyede sembolik oyun davranışında bulunamamalarını hem de zihin kuramına sahip olmadıklarını öne sürerek, OSB'de gözlemlenen sembolik oyun farklarını bu çocukların zihinsel temsil becerilerindeki problemlerle açıklamıştır. Buna göre, OSB olan çocuklar objelerin ikinci ayrıştırılmış temsillerini oluşturamamakta ve sembolik oyunun ve zihin kuramının temelinde yatan 
bu yeti eksikliğinden ötürü çocuklar bu iki beceride de eksiklik göstermektedirler (Baron-Cohen vd., 1985; Leslie, 1987).

Alanyazında Baron-Cohen vd.'nin (1985) çalı̧̧ması gibi OSB'li çocukların zihin kuramında zorlandıklarını, tipik gelişim gösteren çocuklara kıyasla daha geç başarılı olduklarını gösteren birçok çalışma bulunmaktadır (Lam ve Yeung, 2012; Perner vd., 1989; Rutherford ve Rogers, 2003). Bu çalışmalardan bazıları zihin kuramı ve sembolik oyun arasındaki ilişkiyi de incelemektedir. Tipik gelişim gösteren çocuklarda olduğu gibi (Taylor ve Carlson, 1997; Suddendorf vd., 1999), OSB olan çocuklarda da zihin kuramı ile sembolik oyunu anlama ve üretme arasında bir ilişki olduğu görülmüştür.

Bigham (2010), OSB olan, zeka geriliği gösteren ve tipik gelişim gösteren çocuklarla yaptığı çalışmasında, çocukların zihinsel temsil yeteneklerini yanlış inanış zihin kuramı testiyle (örneğin, çocuğun başkasının görmediği bir şey hakkında yanlış inanışa sahip olabileceğini anlama) ölçmüştür. Sembolik oyun anlayışları ise yukarıda bahsedilen Bigham (2008) çalışmasında kullanılan yöntem ile- çocukların başkalarının yaptığı sembolik oyun ve işlevsel oyunu anlama yetilerini ölçen görevler ileölçüldüğünde, OSB olan çocukların zihinsel temsil görevlerindeki performanslarıla sembolik oyun anlayışları arasında bir ilişki bulunmuştur. Lam ve Yeung'un (2012) çalışmasında OSB olan çocukların sembolik oyuna ayırdıkları süre, Lin vd.'nin (2017) çalışmasında ise üretilen sembolik oyunun kalitesi (detay, karmaşıklık ve oyun düzeni) ile zihin kuramı arasında da anlamlı ilişkiler bulunmuştur.

OSB olan çocukların yapılandırılmamış oyunda sembolik oyun davranışlarını seyrek göstermesi ve sembolik oyunun bazı türlerini anlamada yaşadıkları problemler bu gruptaki farklılığın zihinsel temsil becerilerindeki problemlerden kaynaklı olabileceğini desteklemektedir (Bigham, 2008, 2010; Jarrold, vd., 1996). Yapılandırılmış oyunda ve basit sembolik oyunu anlamada kontrol grupları ile ayrışmamaları (Charman ve Baron-Cohen, 1997; Jarrold vd., 1994b, 1996; Kavanaugh ve Harris, 1994) ise çocukların sembolik oyunda sergilemiş oldukları farklılıkları zihinsel temsil becerilerindeki problemlerle açıklamayı zorlaştırmaktadır. Bununla birlikte, sembolik oyun üretimindeki temel sorun zihinsel temsil becerisindeki yetersizlik ise OSB olan çocukların zihinsel temsil gerektirmeyen farklı tür oyunlarda akranlarıyla benzer performans göstermesi beklenebilir. Birçok çalışma bu yönde bulgular sunsa da (Charman ve Baron-Cohen, 1997; Lewis ve Boucher, 1988; Libby vd., 1998) başka çalışmalar OSB olan çocukların genel olarak oyun davranışlarında bir farklılık olduğunu ve bunun sembolik oyuna özel olmayabileceğini savunmaktadır. Örneğin Williams vd.'nin çalışmasında (2001), sadece işlevsel oyunda geçirilen zamana bakıldığında OSB olan çocuklar kontrol gruplarıyla benzer bulunmuş fakat ürettikleri işlevsel oyunun daha basit olduğu belirtilmiştir. $\mathrm{Bu}$ da sorunun zihinsel temsille açıklanmasını zorlaştırmakta ve performans konusundaki farkların bu sorunun altında yatabileceğini düşündürtmektedir. 


\section{Yönetici İslevlerdeki Problemler}

Yönetici işlevler ${ }^{\mathrm{b}}$ beyinde frontal lob ile ilişkili olduğu düşünülen ve hedefe yönelik davranış ve düşünceleri kapsayan üst bilişsel becerileri tanımlayan genel bir terimdir (Zelazo vd., 1997). Miyake vd.'nin (2000) çalışmalarında yönetici işlevler olarak üç temel beceri öne çıkar: çalışan bellek (bilginin bellekte tutulması ve manipüle edilmesi), ketleyici kontrol (baskın olan düşünce veya davranışın bastırılması) ve zihinsel esneklik (düşünce ve davranışları değișen kural veya durumlara göre değiştirebilme). OSB'de yönetici işlevlerde gözlemlenen farklılıkların bu çocuklarda görülen sembolik oyunlardaki çeşitliliği açıklayabileceği düşünülmektedir. Makalenin bu kısmında, yönetici işlevlerin, özellikle ketleyici kontrol ve zihinsel esnekliğin, OSB'de görülen sembolik oyun farklılı̆̆ını nasıl açıklayabileceği incelenecektir.

Ketleyici control. Hill (2004) tarafindan yapılan alanyazın derlemesinde OSB olan kişilerin baskın olan uyaranı ketlemede zorluk çektikleri, bunun da farklı davranışlarla (örneğin, tekrarlanan basmakalıp davranışlar, dürtü kontrolünde problemler) ortaya çıktığı belirtilmiştir. Ketleyici kontrol ve sembolik oyun davranışı arasındaki ilişki incelendiğinde, çocukların yapılandırılmamış koşullarda ürettikleri sembolik oyun davranışı eksikliğinin ketleyici kontrol bozukluğundan kaynaklanabileceğini ileri süren araştırmacılar, sembolik oyun ve zihinsel temsil yaratımı sırasında çocukların gerçek dünyayı baskılamaları gerektiği ve ketlemede sorun yaşayan çocukların bu yüzden sembolik oyun davranışı gösteremediğini belirtmiştir (Harris, 1993; Jarrold vd., 1994a).

Deneysel çalışmalar incelendiğinde, ketleyici kontrolde yaşanan problemler ile sembolik oyun arasındaki ilişsiyi inceleyen çalışmaların görece az sayıda olduğu (Bigham, 2010; Jarrold vd., 1994a) ve var olan bulguların da kesinlikten uzak olduğu gözlenmiştir. Bigham (2008) araştırmasında, OSB olan çocukların objelerin baskın özelliklerinin çocuklardaki bu objeye ait ikinci bir (farklı) zihinsel temsil oluşturmasında problem yaratabileceğini belirtmiştir. Bigham bir objeye 'olmayan' özellikler yükleme davranışını (ördek gerçekte temizken kirliymiş gibi davranma; Kavanaugh ve Harris, 1994) anlamakta zorluk çekmeyen çocukların bir objeyi bir başka obje gibi kullanırken (muz telefonmuş gibi yaparken) zorluk çekmelerinin nedenin o objenin gerçek görünüm ve işlevi olabileceğini savunmuştur. Buna göre çocuklar objenin gerçek özelliklerini baskılayamadıkları için bu objelerle sembolik oyun oynamakta zorlanıyor olabilirler. Bigham (2010) bu ilişkiyi inceleyen çalışmasında, OSB olan çocukların hem sembolik oyunu anlamada hem de ketleyici kontrol görevlerinde tipik gelişim gösteren gruptan anlamlı derecede daha eksik olduklarını, ancak OSB olan grupta ketleyici kontrol ve sembolik oyun arasında anlamlı bir ilişki bulunmadığını belirtmiştir.

Zihinsel Esneklik. OSB olan kişilerin güçlük yaşadıkları başka bir durum ise özgün düşünceler oluşturmak ve davranışlar göstermektir (Turner, 1997). OSB’li çocuklarda görülen sembolik oyun davranışındaki performans düşüklügünün nedeni

\footnotetext{
b 'Yönetici işlevler' (executive functions) terimi Türkçe literatürde 'yürütücü işlevler' olarak da kullanılmaktadır.
} 
olarak da zihinsel esneklik, ya da bu bağlamda üretkenlik (generativity), işlevinde bir eksiklik olduğu ileri sürülmüştür (Jarrold vd., 1996). Üretkenlik eksikliği hipotezine göre, çocukların yapılandırılmamış işlevsel ve sembolik oyun gibi özgün fikirler ortaya koymak zorunda kaldıkları oyunlarda, üretkenlik eksikliğinden ötürü zorluk çekecekleri; ancak yapılandırılmış ve modellenmiş oyunlarda özgün fikir üretmek zorunda kalmayacakları için tipik gelişim gösteren akranlarından ayrışmayacakları ileri sürülmektedir (Lewis ve Boucher, 1995).

Bu görüşü destekler nitelikte, Jarrold vd.’nin (1996) çalışmasında, OSB olan çocukların yapılandırılmamış serbest oyunda sembolik davranış üretmeleri incelenmiş ve orta derece öğrenme güçlüğü gösteren kontrol grubuna göre OSB’li çocukların anlamlı derecede daha az sembolik oyun davranışı gösterdiği belirtilmiştir. Ancak aynı çocuklar oyun yapılandırılmış olduğu zaman sembolik oyun davranışı göstermede diğerlerinden ayrışmamıştır. Jarrold vd. (1996) OSB'li çocukların yapılandırılmış ortamlarda, yani oyunun yönlendirildiği ya da oyunun modellendiği koşullarda, sembolik oyun davranışı gösterdiklerini, oyuncaklara sembolik anlam atfetme ve oyuncakları farklı şekillerde kullanma konusunda zorluk çekmediklerini ancak yapılandırılmamış ve üretkenlik isteyen serbest oyun ortamlarında sembolik oyun davranışı gösteremediklerini öne sürmüştür. Makalenin ilk kısmında alanyazın derlemesinde de belirtildiği gibi araştırmaların büyük bir kısmında OSB olan çocuklar yapılandırılmamış oyunda sembolik oyun davranışı göstermede güçlük çekerken, yapılandırılmış oyunda kontrol grubundan ayrışmamışlardır. Ayrıca, OSB olan çocukların başkalarının yaptığı sembolik oyunu anlamada kontrol gruplarından ayrışmamaları, çocukların sembolik oyunu anlayabildikleri ancak oyun üretimi konusunda üretkenlik yetilerinden kaynaklı olarak zorlandıkları görüşünü desteklemektedir (Jarrold vd., 1993).

Ancak Bigham (2008, 2010) tarafından yapılan çalışmalarda OSB olan çocukların sadece sembolik oyun üretmede değil sembolik oyunu anlamada da zorluk çekmeleri gözlemlenen oyun farklılıklarının üretkenlik kaynaklı sınırlılıklarla ilişkili olduğu görüşünü zayıflatmıştır. Rutherford vd. (2007) da yaptıkları uzun süreli araştırmada OSB olan çocukların hem yapılandırılmış hem de yapılandırılmamış serbest oyun esnasında sembolik oyun davranışı üretmekte zorluk çektiklerini göstermektedir. Ayrıca, Rutherford ve Rogers (2003) üretkenlik ve yapılandırılmamış ortamda gözlemlenen sembolik oyun arasında anlamlı ilişki bulmuş olsa da OSB olan gruptaki üretkenlik performansının tipik gelişim gösteren kontrollerden daha düşük olmaması OSB'de gözlemlenen farkların yalnızca üretkenlikteki problemler ile açıklanmasını zorlaştırmıştır.

Bu kısımda, OSB olan çocuklarda görülen sembolik oyun eksikliğini açıklayan iki alt yönetici işlev bileşeni incelenmiştir. Yönetici işlevlerde görülen işlev bozukluklarının otizmin birçok semptomu ile ilişkili olduğu görüldüğü gibi (Hill, 2004; Turner, 1997) sembolik oyun davranışlarındaki farklar ile de ilişki olduğu öne sürülmüştür (Harris, 1993; Jarrold vd., 1996; Jarrold ve Conn, 2011). Yapılandırılmış oyun görevleri kullanan çalışmalar, OSB olan çocukların sembolik oyun davranışı üretebilecek yetilerinin olduğunu, ancak yönetici işlevlerde, özellikle de ketleyici kontrol ve esneklik/üretkenlikte görülen işlev bozukluklarının çocukların sembolik oyunu uygulamada zorluk çektikleri savını desteklemektedir (Harris, 1993; Lewis ve Boucher, 1995). Ancak, yakın zamanda yapılan çalışmalar OSB olan çocuklarda 
görülen sembolik oyun eksikliğinin yalnızca yönetici işlevlerdeki farklılıklara dayalı bir performans eksikliği ile açıklanamayacağını, zihinsel temsil becerilerindeki yetersizliğin de bu konuda etkili olabileceğini belirtmektedir (Bigham 2010; Lam ve Yeung, 2012).

\section{Motivasyon Eksikliği}

Sembolik oyun davranıșında OSB olan çocuklarda görülen eksiklik/farklılığın zihinsel temsil yeteneğindeki problem ve yönetici işlevlerdeki eksikliğe ek olarak motivasyon eksikliği ile de açıklanabileceği düşünülmektedir (Hobson vd., 2009). Koegel ve Mentis (1985) yaptıkları derlemede, OSB olan çocukların sosyal öğrenme gibi çeşitli durumlarda sık sık başarısızlığa uğramalarından ötürü çocuklarda genel bir motivasyon eksikliği olduğunu ileri sürmüş ve OSB olan çocukların motivasyon eksikliği çekmedikleri ya da motive edildikleri durumlarda tipik gelişim gösteren akranları ile benzer performanslar gösterebileceklerini iddia etmişlerdir.

$\mathrm{Bu}$ perspektife göre, OSB olan çocukların sembolik oyunu üretmede yaşadıkları zorluklar çocukların bu oyuna karşı ilgilerinin olmamasıyla açıklanabilir. Hobson vd. de (2009) araştırmalarında OSB olan çocukların objeleri başka objelerin yerine kullanma ve oyuncakları işlevlerine uygun kullanma gibi sembolik oyun davranışının mekanik yönlerini gösterebildiklerini; ancak OSB olan çocukların sembolik anlam oluşturma, yaratıcılık ve eğlence gibi sembolik oyun özelliklerini yerine getirmede tipik gelişim gösteren kontrol grubundan anlamlı derecede eksik olduklarını göstermiştir. Hobson vd. (2009) sembolik oyunu yaratıcı ve eğlenceli hale getiren motivasyon ve duygusal alanlarda, OSB olan çocukların eksiklik çektiklerini belirtmiş, bunun da çocukların farklı koşullarda bu oyunda yaşadıkları problemleri açıklayabileceğini öne sürmüştür. Ancak, alanyazında motivasyon eksikliği ve sembolik oyun davranışları arasındaki ilişkiyi ampirik olarak inceleyen bir çalışma mevcut değildir.

\section{Sonuç}

Erken çocukluk ve gelişimde önemli bir yeri olan ve tipik gelişim gösteren çocuklarda iki yaş itibariyle ortaya çıkan sembolik oyun davranışı çeşitli sosyal ve bilişsel becerilerle ilişkilendirilmektedir (Lillard vd., 2013). Dolayısıyla bu tür oyunun hem tipik gelişim gösteren hem de gelişimsel farklılıkları olan gruplardaki seyrini anlamak sadece ebeveynler için değil, aynı zamanda çocuk gelişimi çalışan araştırmacılar ve alanda çalışan danışman ve öğretmenler için de faydalı olacaktır. Bu derlemede, hayal gücüne dayalı oyun türlerinden olan sembolik oyunun farklı gelişim gösterdiği bir grup olan OSB olan katılımcılar ile yapılan çalışmalar incelenmiş ve bu gelişimi açıklayan farklı perspektifler ele alınmıştır. Taranan çalışmaların sonuçları ve bu sonuçların OSB'deki farkları açıklamaya yönelik çıkarımlar oldukça çeşitlilik göstermektedir.

Bütün bu çalışmalar göz önüne alındığında, OSB olan çocukların temel olarak yapılandırılmamış koşullarda sembolik oyunu kendiliklerinden üretmede problem yaşadıkları sonucuna varılabilir. Bu bulgular zihinsel temsille ilgili problemlerden kaynaklı olabileceği gibi üretkenlik, gerçekliği ketleyememe ve/veya motivasyon eksikliği ile de açıklanabilir. OSB olan çocukların bazı sembolik oyun türlerini kavramada gösterdikleri sınırlılıklar (Bigham, 2008, 2010) ve çocukların zihin kuramı 
testlerindeki performanslarıyla çocukların sembolik oyun performansları arasında bulunan ilişki OSB olan çocuklardaki zihinsel temsil becerisindeki problemlere işaret eder. Ancak, OSB olan çocukların başkasının yaptığı bazı sembolik oyun davranışlarını anlamakta zorluk çekmemesi (Jarrold vd., 1994b; Kavanaugh ve Harris, 1994) ve yönergelerin verildiği yapılandırılmış ya da yarı-yapılandırılmış koşullarda serbest oyun koşullarına kıyasla daha fazla sembolik oyun göstermesi (Lewis ve Boucher, 1988) OSB'de gözlenen farkları sadece zihinsel temsil becerilerindeki yetersizlikle açıklamayı zorlaştırır. Zihinsel olarak yeterli olsalar bile çocukların yönetici işlev becerilerinde yaşadıkları problemler (örn., ketleyici kontrolde yaşanan problemler) ve bu tür oyuna karşı düşük motivasyon OSB olan çocuklarda rastlanan sembolik oyun farklarını açıklamada önemli faktörler olabilir.

Kısacası, OSB olan çocukların sembolik oyun performanslarını ve bu performansta meydana gelen farklılıkları açıklayabilecek faktörler önem taşımakta ve daha fazla araştırma yapılmasına ihtiyaç duyulmaktadır. Bu sayede hem OSB olan çocukların tipik gelişim gösteren çocuklara kıyasla gelişimsel seyrine dair daha detaylı bilgi sahibi olunacak olup hem de eğitim alanında OSB olan çocukların gelişimlerini desteklemek amacıyla müdahale programları geliştirilmesine olanak sağlanacaktır.

\section{Araştırmacı ve Eğitimcilere Yönelik Öneriler}

OSB olan çocuklarda gözlemlenen farklılıkların yeterlilikten mi yoksa performanstan kaynaklı mı olduğunu daha iyi anlayabilmek için hem boylamsal çalışmalar hem de müdahale çalışmaları oldukça yol gösterici kaynaklar olacaktır. Örneğin, OSB olan çocukların yönetici işlevler alanında bir eğitim programına katıldıkları koşulda zihinsel temsil ve sembolik oyun becerilerinin nasıl gelişeceğinin araştırılması bu konuda önemli bir adım olabilir.

Ek olarak, özellikle motivasyon eksikliği açıklamasını test etmek için OSB olan çocukların özel ilgi alanlarının kullanılması düşünülebilir. Özel ilgi alanları (kimi zaman sınırlı ve yoğun ilgi alanları olarak da ifade edilir), çocukların bir konu ya da aktiviteye çok yoğun ilgi duyması olarak tanımlanır (Klin vd., 2007) ve OSB'nin tanımlayıcı özelliklerinden biri olarak kabul edilir (APA, 2013; Wood, 2021). OSB olan çocukların özel ilgi alanlarının onlar için faydalı olabileceği farklı çalışmalarda gösterilmiştir (Koegel vd., 2012; Winter-Messiers, 2007). Örneğin, sınırlı/özel ilgi alanlarında daha yaratıcı (Porter, 2012) olabilen OSB'li çocukların aynı zamanda özel ilgi alanları söz konusu olduğunda sosyal becerilerinin (Gunn ve Delafield-Butt, 2016) ve iletişim becerilerinin de daha iyi olduğu bulunmuştur (Winter-Messiers, 2007). Motivasyon eksikliği açıklaması çocukların sembolik oyun üretimlerinde gözlemlenen zorlanmanın kaynağının kurulan oyuna olan ilgisizlik olabileceğini öne sürmektedir. Bu çerçevede, motivasyon eksikliği açıklamasını test etmek için özel ilgi alanlarının kullanılması OSB olan çocukların sembolik oyun becerilerini ölçmek için değerlendirilebilir. Böyle bir durumda çocuklar kendi ilgi alanlarında ve bildikleri bir konuda, içten gelen bir motivasyonla oyun kurmaları gerektiğinde sembolik oyun üretmede zorluk çekmeyebilir ve hatta yaratıcılıklarını kullanabilirler. Bu doğrultuda OSB'li çocukların özel eğitim içeriklerinde çocuk bazlı ilerlenmesi ve her çocuğun özel ilgi alanlarına yönelik nesneler sunulması çocukların sembolik gelişimlerine fayda sağlayabilir. 


\section{Kaynakça}

American Psychiatric Association. (2013). Diagnostic and statistical manual of mental disorders (DSM-5). APA.

Barbaro, J. ve Dissanayake, C. (2013). Early markers of autism spectrum disorders in infants and toddlers prospectively identified in the social communication and attention study. Autism, 17, 64-86.

Baron-Cohen, S. (1987). Autism and symbolic play. British Journal of Developmental Psychology, 5, 139-148.

Baron-Cohen, S., Leslie, A. M. ve Frith, U. (1985). Does the autistic child have a "theory of mind"?. Cognition, 21, 37-46.

Bigham, S. (2008). Comprehension of pretence in children with autism. British Journal of Developmental Psychology, 26, 265-280.

Bigham, S. (2010). Impaired competence for pretense in children with autism: Exploring potential cognitive predictors. Journal of Autism and Developmental Disorders, 40, 30-38.

Campbell, S. B., Leezenbaum, N. B., Mahoney, A. S., Moore, E. L. ve Brownell, C. A. (2016). Pretend play and social engagement in toddlers at high and low genetic risk for autism spectrum disorder. Journal of Autism and Developmental Disorders, 46, 2305-2316.

Charman, T. ve Baron-Cohen, S. (1997). Brief report: Prompted pretend play in autism. Journal of Autism and Developmental Disorder, 27, 325-332.

Charman, T., Swettenham, J., Baron-Cohen, S., Cox, A., Baird, G. ve Drew, A. (1997). Infants with autism: An investigation of empathy, pretend play, joint attention and imitation. Developmental Psychology, 33, 781-789.

Christensen, L., Hutman, T., Rozga, A., Young, G. S., Ozonoff, S., Rogers, S. J., Baker, B. ve Sigman, M. (2010). Play and developmental outcomes in infant siblings of children with autism. Journal of Autism and Developmental Disorders, 40, 946957.

Davis, P. E., Simon, H., Meins, E. ve Robins, D. L. (2018). Imaginary companions in children with autism spectrum disorder. Journal of Autism and Developmental Disorders, 48, 2790-2799.

Dominguez, A., Ziviani, J. ve Rodger, S. (2006). Play behaviours and play object preferences of young children with autistic disorder in a clinical play environment. Autism, 10, 53-69.

Gleason, T. R. ve Hohmann, L. M. (2006). Concepts of real and imaginary friendships in early childhood. Social Development, 15, 128-144.

González-Sala, F., Gómez-Marí, I., Tárraga-Mínguez, R., Vicente-Carvajal, A. ve Pastor-Cerezuela, G. (2021). Symbolic play among children with Autism Spectrum Disorder: A scoping review. Children, 8(9), 801.

Gunn, K. C. ve Delafield-Butt, J. T. (2016). Teaching children with autism spectrum disorder with restricted interests: A review of evidence for best practice. Review of Educational Research, 86, 408-430.

Harris, P. L. (1993). Pretending and planning. S. Baron-Cohen, H. Tager-Flusberg ve D. Cohen (Haz.) Understanding other minds: Perspectives from Autism (s. 228246). Oxford University Press. 
Hill, E. L. (2004). Evaluating the theory of executive dysfunction in autism. Developmental Review, 24, 189-233.

Hobson, J., Hobson, R. P., Malik, S., Bargiota, K. ve Calo, S. (2013). The relation between social engagement and pretend play in autism. British Journal of Developmental Psychology, 31, 114-127.

Hobson, R. P., Lee, A. ve Hobson, J. A. (2009). Qualities of symbolic play among children with autism: A social-developmental perspective. Journal of Autism and Developmental Disorders, 39(1), 12-22.

Jarrold, C. (2003). A review of research into pretend play in autism. Autism, 7, 379-390.

Jarrold, C., Boucher, J. ve Smith, P. K. (1993). Symbolic play in autism: A review. Journal of Autism and Developmental Disorders, 23, 281-307.

Jarrold, C., Boucher, J. ve Smith, P. K. (1994a). Executive function deficits and the pretend play of children with autism: A research note. Journal of Child Psychology and Psychiatry, 35, 1473-1482.

Jarrold, C., Boucher, J. ve Smith, P. K. (1996). Generativity deficits in pretend play in autism. British Journal of Developmental Psychology, 14, 275-300.

Jarrold, C. ve Conn, C. (2011). The development of pretend play in autism. A. Pellegrini (Haz.), The Oxford handbook of the development of play (s. 308-321). Oxford University Press.

Jarrold, C., Smith, P. K., Boucher, J. ve Harris, P. (1994b). Comprehension of pretense in children with autism. Journal of Autism and Developmental Disorders, 24, 433-455.

Kasirer, A., Adi-Japha, E. ve Mashal, N. (2020). Verbal and figural creativity in children with autism spectrum disorder and typical development. Frontiers in Psychology, 11, 559238.

Kavanaugh, R. D. ve Harris, P. L. (1994). Imagining the outcome of pretend transformations: Assessing the competence of normal children and children with autism. Developmental Psychology, 30, 847-854.

Klin, A., Danovitch, J. H., Merz, A. B. ve Volkmar, F. R. (2007). Circumscribed interests in higher functioning individuals with autism spectrum disorders: An exploratory study. Research and Practice for Persons with Severe Disabilities, 32, 89-100.

Koegel, R. L. ve Mentis, M. (1985). Motivation in childhood autism: Can they or won't they?. Journal of Child Psychology and Psychiatry, 26, 185-191.

Koegel, L. K., Vernon, T. W., Koegel, R. L., Koegel, B. L. ve Paullin, A. W. (2012). Improving social engagement and initiations between children with autism spectrum disorder and their peers in inclusive settings. Journal of Positive Behavior Interventions, 14, 220-227.

Lam, Y. G. ve Yeung, S. S. S. (2012). Cognitive deficits and symbolic play in preschoolers with autism. Research in Autism Spectrum Disorders, 6(1), 560564.

Leslie, A. (1987). Pretense and representation: The origins of "Theory of Mind". Psychological Review, 9, 412-426.

Lewis, V. ve Boucher, J. (1988). Spontaneous, instructed and elicited play in relatively able autistic children. British Journal of Developmental Psychology, 6, 325-339. 
Lewis, V. ve Boucher, J. (1995). Generativity in the play of young people with autism. Journal of Autism and Developmental Disorders, 25, 105-121.

Libby, S., Powell, S., Messer, D. ve Jordan, R. (1997). Imitation of pretend play acts by children with autism and Down syndrome. Journal of Autism and Developmental Disorders, 27, 365-383.

Libby, S., Powell, S., Messer, D. ve Jordan, R. (1998). Spontaneous play in children with autism: A reappraisal. Journal of Autism and Developmental Disorders, 28, 487-497.

Lillard, A. S., Lerner, M. D., Hopkins, E. J., Dore, R. A., Smith, E. D. ve Palmquist, C. M. (2013). The impact of pretend play on children's development: A review of the evidence. Psychological Bulletin, 139, 1-34.

Lin, S. K., Tsai, C. H., Li, H. J., Huang, C. Y. ve Chen, K. L. (2017). Theory of mind predominantly associated with the quality, not quantity, of pretend play in children with autism spectrum disorder. European Child \& Adolescent Psychiatry, 26, 1187-1196.

Miyake, A., Friedman, N. P., Emerson, M. J., Witzki, A. H., Howerter, A. ve Wager, T. D. (2000). The unity and diversity of executive functions and their contributions to complex "frontal lobe" tasks: A latent variable analysis. Cognitive Psychology, 41, 49-100.

Morgan, B., Maybery, M. ve Durkin, K. (2003). Weak central coherence, poor joint attention, and low verbal ability: Independent deficits in early autism. Developmental Psychology, 39, 646-656.

Motoshima, Y., Shinohara, I., Todo, N. ve Moriguchi, Y. (2014). Parental behaviour and children's creation of imaginary companions: A longitudinal study. European Journal of Developmental Psychology, 11, 716-727.

Mundy, P., Sigman, M., Ungerer, J. ve Sherman, T. (1986). Defining the social deficits of autism: The contribution of non-verbal communication measures. Journal of Child Psychology and Psychiatry, 27, 657-669.

Naber, F. B., Bakermans-Kranenburg, M. J., van Ijzendoorn, M. H., Swinkels, S. H., Buitelaar, J. K., Dietz, C., van Daalen, E. ve van Engeland, H. (2008). Play behavior and attachment in toddlers with autism. Journal of Autism and Developmental Disorders, 38(5), 857-866.

Perner, J., Frith, U., Leslie, A. M. ve Leekam, S. R. (1989). Exploration of the autistic child's theory of mind: Knowledge, belief, and communication. Child Development, 689-700.

Porter, N. (2012). Promotion of pretend play for children with high-functioning autism through the use of circumscribed interests. Early Childhood Education Journal, 40, 161-167.

Rutherford, M. D. ve Rogers, S. J. (2003). Cognitive underpinnings of pretend play in autism. Journal of Autism and Developmental Disorders, 33, 289-302.

Rutherford, M. D., Young, G. S., Hepburn, S. ve Rogers, S. J. (2007). A longitudinal study of pretend play in autism. Journal of Autism and Developmental Disorders, 37, 1024-1039.

Scott, F. J. (2013). The development of imagination in children with autism. M. Taylor (Haz.), The Oxford handbook of the development of imagination (s. 499-515). Oxford University Press 
Suddendorf, T., Fletcher-Flinn, C. ve Johnston, L. (1999). Pantomime and theory of mind. The Journal of Genetic Psychology, 160, 31-45.

Taylor, M. (1999). Imaginary companions and the children who create them. Oxford University Press.

Taylor, M. ve Carlson, S. M. (1997). The relation between individual differences in fantasy and theory of mind. Child Development, 68, 436-455.

Thiemann-Bourque, K. S., Brady, N. C. ve Fleming, K. K. (2012). Symbolic play of preschoolers with severe communication impairments with autism and other developmental delays: More similarities than differences. Journal of Autism and Developmental Disorders, 42, 863-873.

Turner, M. (1997). Towards an executive dysfunction account of repetitive behaviour in autism. J. Russell (Haz.), Autism as an executive disorder (s. 57-100). Oxford University Press.

Williams, E., Reddy, V. ve Costall, A. (2001). Taking a closer look at functional play in children with autism. Journal of Autism and Developmental Disorders, 31(1), 67-77.

Wilson, K. P., Carter, M. W., Wiener, H. L., DeRamus, M. L., Bulluck, J. C., Watson, L. R., Crais, E. R. ve Baranek, G. T. (2017). Object play in infants with autism spectrum disorder: A longitudinal retrospective video analysis. Autism \& Developmental Language Impairments, 2, 1-12.

Wing, L., Gould, J., Yeates, S. R. ve Brierley, L. M. (1977). Symbolic play in severely mentally retarded and in autistic children. Journal of Child Psychology and Psychiatry, 18, 167-178.

Winter-Messiers, M. A. (2007). From tarantulas to toilet brushes: Understanding the special interest areas of children and youth with Asperger syndrome. Remedial and Special Education, 28, 140-152.

Wood, R. (2021). Autism, intense interests and support in school: From wasted efforts to shared understandings. Educational Review, 73, 34-54.

Zelazo, P. D., Carter, A., Reznick, J. S. ve Frye, D. (1997). Early development of executive function: A problem-solving framework. Review of General Psychology, 1, 198-226. 


\title{
Symbolic Play in Children with Autism Spectrum Disorder
}

\begin{abstract}
Children with Autism Spectrum Disorder (ASD) are known to have problems in social communication and engage in repetitive, stereotypical behaviors. There are studies investigating the developmental differences in children with ASD in activities that require imagination and creativity. It is especially important to study differences in symbolic play in children with ASD compared to typically developing children or to children with other developmental delays in order to understand the development of symbolic play in this group as well as understanding cognitive development in general. In this review, studies investigating comprehension of and engagement in symbolic play in children with ASD are reviewed and different perspectives that attempt to explain the limitations observed in this group are discussed. Based on the reviewed studies, it can be concluded that children with ASD differ from the control groups in spontaneous pretend play (e.g., spending less time in this type of play, engaging in less sophisticated play behaviors) and that these differences can be attributed to both competence performance problems.
\end{abstract}

Keywords: Autism Spectrum Disorder (ASD), symbolic play, pretend play, imagination, metarepresentatio 